\title{
A Rare Case of Pulmonary Infection: Endobronchial Actinomycosis
}

\author{
Nadir Bir Akciğer Enfeksiyonu Olgusu: Endobronşiyal Aktinomikoz
}

Serhat Özgün' , Büşra Yaprak Bayrak², Tuba Çiffçi Küsbec ${ }^{i 3}$, Ahmet Ilgazlı ${ }^{4}$

\section{Abstract}

Pulmonary actinomycosis is a bacterial disease that can be difficult to diagnose due to its nonspecific clinical and radiological findings caused by actinomyces. A 59-year-old female patient presented with a history of coughing and white sputum for the last one year. Here, we present a rare case of endobronchial actinomycosis with an endobronchial lesion obstructing the basal segments of the right lower lobe, diagnosed from a transbronchial biopsy taken during a fiberoptic bronchoscopy.

Key words: Actinomycosis, endobronchial, bronchoscop.

\section{Özet}

Pulmoner aktinomikozis, aktinomiçes türlerinin neden olduğu, nonspesifik klinik ve radyolojik bulguları olması nedeni ile tanı konulmasında güçlük yaşanan bakteriyel bir hastalıktır. Elli dokuz yaşında kadın hasta, son bir yıldır devam eden öksürük ve beyaz renkli balgam şikâyeti ile başvurdu. Burada, fiberoptik bronkoskopide sağ alt lob bazal segmentleri obstrükte eden, endobronşial lezyon görülen ve transbronşiyal biyopsi ile tanı konulan endobronşiyal aktinomikoz olgusu, nadir görülmesi nedeniyle sunuldu.

Anahtar Sözcükler: Aktinomikoz, endobronşiyal, bronkoskopi.
'Department of Chest Diseases, Kocaeli University Faculty of Medicine, Kocaeli, Turkey

${ }^{2}$ Department of Pathology, Kocaeli University Faculty of Medicine, Kocaeli, Tukey

${ }^{3}$ Department of Chest Diseases, Yozgat City Hospital, Yozgat, Turkey

${ }^{4}$ Department of Chest Diseases, Kocaeli University Faculty of Medicine, Kocaeli, Turkey
'Kocaeli Universtesi Tıp Fakültesi, Göğüs Hastalıkları Anabilim Dalı, Kocaeli

${ }^{2}$ Kocaeli Universtesi Tıp Fakültesi, Tıbbi Patoloji Anabilim Dalı, Kocaeli

${ }^{3}$ Yozgat Şehir Hastanesi, Göğüs Hastalıkları Kliniği, Yozgat

${ }^{4}$ Kocaeli Universtesi Tıp Fakültesi,Göğüs Hastalıkları Anabilim Dalı, Kocaeli

Submitted (Başvuru tarihi): 23.07.2020 Accepted (Kabul tarihi): 13.1 1.2020

Correspondence (iletişim): Serhat Özgün, Department of Chest Diseases, Kocaeli University Faculty of Medicine, Kocaeli, Turkey

e-mail: serhatozgun@hotmail.com 
Actinomycosis is a rare chronic and infectious disease caused by bacteria known as actinomyces. It is a nonacid resistant gram-positive anaerobic bacterium of the Actinomyceataceae family. Pulmonary actinomycosis is an endogenous infection that likely develops as a result of aspiration of oropharyngeal or gastrointestinal secretions, occurring as a result of the actinomyces in the normal flora entering the damaged mucosa (1-3). All systems in the body may be affected, but the most common form of the disease is the cervicofacial type. The pulmonary involvement has been reported to be around $15 \%$ in all cases (4). Its resemblance to tuberculosis, lung abscess and lung cancer, both clinically and radiologically, may lead to misdiagnosis and delay in diagnosis (5). Here, we present a 59-year-old woman with endobronchial actinomycosis with complaints of cough and sputum, despite treatment for pneumonia.

\section{CASE}

A 59-year-old female patient was admitted to our clinic with cough and white sputum for the last one year. Intermittent antibiotic treatment led to a partial response. The patient was admitted to our clinic after the complaints continued. The patient was subfebrile, with no complaints of hemoptysis, chest pain or night sweats. She had been using oral antidiabetic agents for the treatment of type II diabetes mellitus for 5 years. There was no smoking history. A physical examination revealed her general status to be good and her vital signs to be stable. A chest examination identified crackles over the right lower lobe. The laboratory values at admission included a white blood cell count of $5.1 \times 10^{3} / \mu \mathrm{L}$, an erythrocyte sedimentation rate of $18 \mathrm{~mm} / \mathrm{h}$, a hemoglobin value of $11.7 \mathrm{~g} / \mathrm{dL}$, a hematocrit value of $38 \%$ and a mean corpuscular volume value of 80 (MCV) fL. In the biochemical analysis, and abnormal C-reactive protein value of $22.46 \mathrm{mg} / \mathrm{L}$ (normal value $<5 \mathrm{mg} / \mathrm{L}$ ) was recorded. A chest X-Ray revealed a nonhomogeneous density beat in the right lower zone (Figure 1). The patient, who lost $4 \mathrm{~kg}$ in the last year, was examined by fiberoptic bronchoscopy for tuberculosis and lung cancer. Bronchoscopy revealed an endobronchial lesion obstructing the basal segments of the right lower lobe (Figure 2). Bronchoalveolar lavage and bronchial biopsies were taken, and a pathological examination revealed characteristic sulfur granules of Actinomyces admixed with neutrophils and numerous neutrophil-laden histiocytes (Figure 3). Fungal, bacterial and mycobacterial smears were negative in the bronchoalveolar lavage. The patient was diagnosed with actinomycosis, and was start- ed on intravenous sulbactam-ampicillin $4 \mathrm{x} 1 \mathrm{~g}$ treatment. In the first month of treatment, the complaints of cough and sputum resolved. The treatment was continued for 4 weeks. Oral amoxicillin-clavulanate 2x1 g treatment was started after intravenous sulbactam-ampicillin treatment. The patient's symptoms and radiological findings regressed in the third month of treatment (Figure 4), and having benefited from the treatment, the patient is in the third month of follow-up with continued oral treatment as an outpatient.

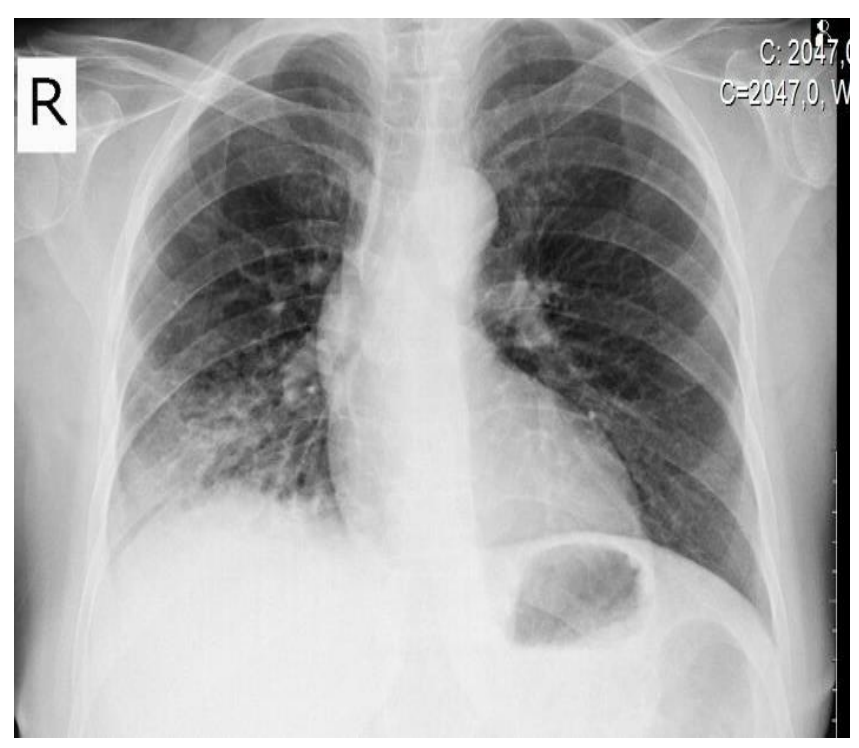

Figure 1: Chest $X$-ray displaying a nonhomogeneous density beat in the right lower zone

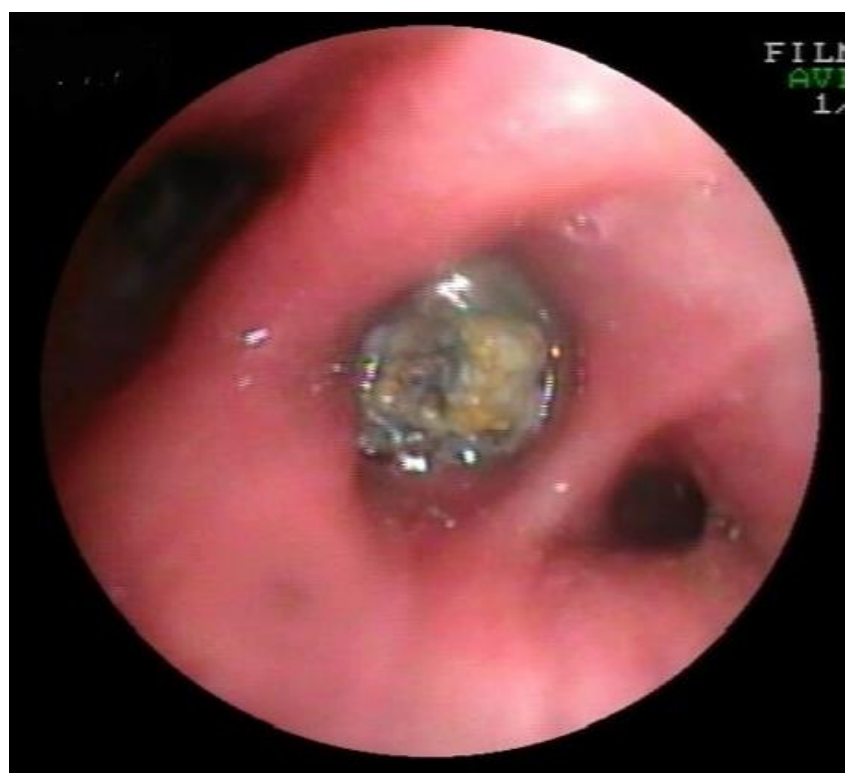

Figure 2: Fiberoptic bronchoscopy showing an obstruction of the basal segments of the right lower lobe with an exophytic endobronchial lesion 


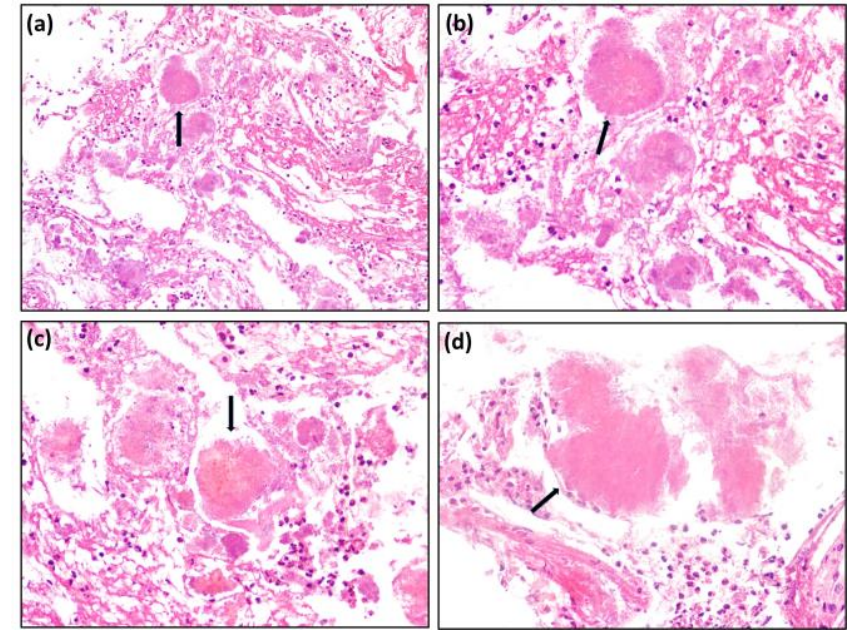

Figure 3: Basophilic clusters with eosinophilic terminal clubs, identified as sulfur granules (black arrow) and active chronic inflammation. Characteristic sulfur granules of Actinomyces, admixed with neutrophils, numerous neutrophil-laden histiocytes. (Hematoxylin \& Eosin, x200 (a); $x 400(b, c, d)$

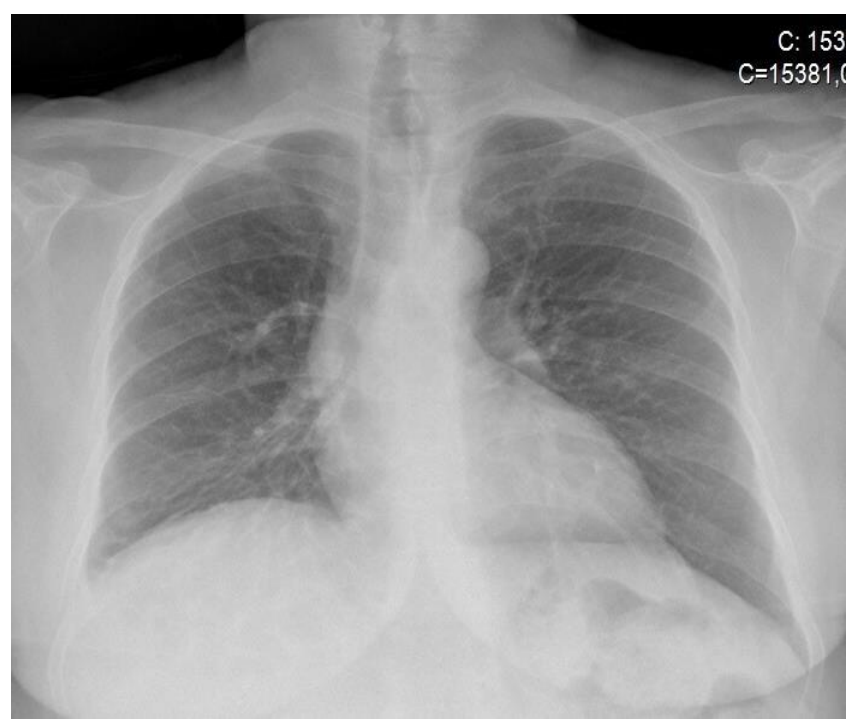

Figure 4: Chest $X$-ray in the third month of treatment

\section{DISCUSSION}

Pulmonary actinomycosis continues to be a significant problem for clinicians, as symptoms are non-specific, and the disease resembles other chronic suppurative chest diseases and malignancies. Fever, cough, sputum, shortness of breath, weakness, weight loss, night sweats, chest pain and hemoptysis are the main symptoms $(2,6)$. Our case presented with complaints of a cough and sputum for the last one year. Chronic respiratory diseases such as emphysema, chronic bronchitis, bronchiectasis and alcoholism, poor oral hygiene, periodontal disease and surgery, facial trauma and diabetes mellitus are all predisposing factors for the disease (7). The leading risk factor in our patient was uncontrolled type 2 diabetes mellitus with hyperglycemia. The laboratory findings of the disease are nonspecific, as normochromic anemia, leukocytosis with polymorphonuclear leukocyte dominance and low C-reactive protein increase can be observed (7). Among these, high levels of C-reactive protein were present in our patient. In Kim et al.'s (8) study of 94 cases diagnosed between 2000 and 2010, 44 were reported to have never smoked, while an evaluation of radiological images revealed that all but six cases had been misdiagnosed initially, with the most common diagnosis being cancer, accounting for 35.1\%. Our case never smoked. A bronchoscopy was planned following a diagnosis of malignancy and tuberculosis in the patient indicating that she had been weakened by $4 \mathrm{~kg}$ for the last year and did not pass his complaints despite her intermittently antibiotic use. The optimum approach to the diagnosis of actinomycosis is the pathological examination of specimens taken by biopsy and the production of microorganisms in culture (9). Bronchoscopy may reveal an exophytic mass with purulent exudate and a characteristic histology with sulfur granules (6). Our case was diagnosed from a biopsy following bronchoscopy. Actinomycosis was first treated with penicillin in the 1940s, and this approach still prevails (10). Beta-lactam antibiotics are frequently preferred as a treatment approach, and the duration of treatment is long (9). Alternatives are tetracycline, erythromycin, chloramphenicol, clindamycin and imipenem, especially in patients with penicillin allergies (7,11-13). Surgical treatment can be particularly helpful for complications such as pulmonary abscesses and empyema, in situations where fistula and sinuses need to be drained, or for the control of life-threatening hemoptysis $(14,15)$. We started treatment with intravenous sulbactam-ampicillin $4 \times 1 \mathrm{~g}$, and switched to oral amoxicillin-clavulanate $2 x \lg$ treatment at the end of the first month following clinical and radiological improvement.

\section{CONCLUSION}

Pulmonary actinomycosis is still a significant problem for clinicians. Fiberoptic bronchoscopy is an important diagnostic tool, as it can lead to the avoidance of surgical procedures. We present this case to suggest pulmonary actinomycosis be kept in mind as a differential diagnosis in late response pneumonia or recurrences.

\section{CONFLICTS OF INTEREST}

None declared. 


\section{AUTHOR CONTRIBUTIONS}

Concept - S.Ö., B.Y.B., T.Ç.K., A.I.; Planning and Design - S.Ö., B.Y.B., T.Ç.K., A.I.; Supervision - S.Ö., B.Y.B., T.Ç.K., A.I.; Funding - S.Ö., B.Y.B.; Materials - S.Ö., A.I.; Data Collection and/or Processing - S.Ö., A.I.; Analysis and/or Interpretation - S.Ö., B.Y.B.; Literature Review S.Ö., A.I.; Writing - S.Ö., A.I.; Critical Review - S.Ö., A.I.

\section{YAZAR KATKILARI}

Fikir - S.Ö., B.Y.B., T.Ç.K., A.I.; Tasarım ve Dizayn - S.Ö., B.Y.B., T.Ç.K., A.I.; Denetleme - S.Ö., B.Y.B., T.Ç.K., A.I.; Kaynaklar - S.Ö., B.Y.B.; Malzemeler - S.Ö., A.I.; Veri Toplama ve/veya İşleme - S.Ö., A.I.; Analiz ve/veya Yorum - S.Ö., B.Y.B.; Literatür Taraması - S.Ö., A.I.; Yazıyı Yazan - S.Ö., A.I.; Eleştirel İnceleme - S.Ö., A.I.

\section{REFERENCES}

1. Bennhoff DF. Actinomycosis: diagnostic and therapeutic considerations and a review of 32 cases. Laryngoscope 1984; 94:1198-217. [CrossRef]

2. Frank $P$, Strickland B. Pulmonary actinomycosis. Br J Radiol 1974; 47:373-8. [CrossRef]

3. Kaya D, Demirezen S, Beksac MS. Aktinomikoza genel bir bakış. Turkiye Klin J Med Sci 2009; 29:510-9.

4. Santos JW, Zambenedetti RM, Mann KC, Cibin LF. Thoracic actinomycosis: report of a patient with advancedstage disease. Braz J Infect Dis 2007; 11:157-9. [CrossRef]

5. Davies SF, Sarosi GA. Pulmonary Fungal Infection. In: Crappo JD, Glas J, Karlinsky J, King, JR TE, eds. Baum's Textbook Pulmonary Diseases. Philadelphia: Lippincott Williams Wilkins, 2004:341-71.

6. Barikbin P, Grosser K, Hahn G, Fischer R, Suttorp M. Thoracic actinomycosis imitating a malignant chest wall tumor. Diagnosis: pulmonary actinomycosis. J Pediatr Hematol Oncol 2007; 29:345-6. [CrossRef]

7. Mabeza GF, Macfarlane J. Pulmonary actinomycosis. Eur Respir J 2003; 21:545-51. [CrossRef]

8. Kim SR, Jung LY, Oh IJ, Kim YC, Shin KC, Lee MK, et al. Pulmonary actinomycosis during the first decade of $21 \mathrm{st}$ century: cases of 94 patients. BMC Infect Dis 2013; 13:216. [CrossRef]

9. Valour F, Sénéchal A, Dupieux C, Karsenty J, Lustig S, Breton $\mathrm{P}$, et al. Actinomycosis: etiology, clinical features, diagnosis, treatment, and management. Infect Drug Resist $2014 ;$ 7:183-97. [CrossRef]

10. de Feiter PW, Soeters PB. Gastrointestinal actinomycosis: an unusual presentation with obstructive uropathy: report of a case and review of the literature. Dis Colon Rectum 2001; 44:1521-5. [CrossRef]

11. Poey C, Giron J, Verhaegen F, Levenes H, Gruels S, Fajadet $P$, et al. $X$-ray computed tomographic and radiographic aspects of thoracic actinomycosis. J Radiol 1996; 77:177-83.

12. Cobellis L, Messalli EM, Pierno G. Pelvic actinomycosis in menopause: a case report. Maturitas 2001; 39:79-81. [CrossRef]

13. Choi J, Koh WJ, Kim TS, Lee KS, Han J, Kim H, et al. Optimal duration of IV and oral antibiotics in the treatment of thoracic actinomycosis. Chest 2005; 128:22117. [CrossRef]

14. Endo S, Murayama F, Yamaguchi T, Yamamoto S, Otani $S$, Saito $N$, et al. Surgical considerations for pulmonary actinomycosis. Ann Thorac Surg 2002; 74:185-90. [CrossRef]

15. Boudaya MS, Smadhi $H$, Marghli A, Mouna M, Charmiti $\mathrm{F}$, Ismail $\mathrm{O}$, et al. Surgery in thoracic actinomycosis. Asian Cardiovasc Thorac Ann 2012; 20:314-9. [CrossRef] 